Part of Journal of Research of the National Bureau of Standards, Volume 31, September 1943

\title{
PROPERTIES OF CAST RED BRASS AS AFFECTED BY THE AMBIENT ATMOSPHERE DURING MELTING
}

\author{
By Harold B. Gardner, ${ }^{1}$ Alexander I. Krynitsky, and Charles M. Saeger, Jr.
}

\section{ABSTRACT}

A study was made of the physical properties of red brass (Cu, 85; Sn, 5; Pb. 5; $\mathrm{Zn}, 5)$, melts of which had been made and poured in an atmosphere of hydrogen, nitrogen, methane, carbon dioxide, carbon monoxide, and air. The tensile properties, hardness, density, and electrical resistivity of the sand-cast bars, in general were inferior to those of the chill-cast metal. For both the sand-cast and chill-cast bars, hydrogen and methane had deleterious effects. The effect of hydrogen was most pronounced and detrimental. The unsoundness of the hydrogen-treated metal, as shown by microstructural study and by density surveys, is the most important factor responsible for the inferior properties of the metal treated in this way.

\section{CONTENTS}

I. Introduction

II. Method of investigation and materials

III. Results _

1. Chemical composition

2. Tensile properties and hardness

3. Density _... 131

4. Electrical resistivity

5. Running quality

6. Soundness of castings

7. Microstructure

8. Melting in vacuum

IV. Discussion,

V. Summary _.

VI. References

\section{INTRODUCTION}

The work summarized in this report is the concluding phase of a rather extensive study of the characteristics of red brass, Cu 85, Sn 5, $\mathrm{Pb} \mathrm{5,} \mathrm{Zn} \mathrm{5.} \mathrm{The} \mathrm{preceding} \mathrm{phases} \mathrm{of} \mathrm{the} \mathrm{investigation,} \mathrm{the} \mathrm{results}$ of which have been published $[1,2,3,4]^{2}$ related to the effects of specific impurities in the alloy. In the present report, the effects of "gaseous" impurities are considered; that is, the effects which can be attributed to the action of the atmosphere that envelops the metal during melting and pouring. The general investigation was carried out by the Bureau in cooperation with the Non-Ferrous Ingot

\footnotetext{
${ }_{1}^{1}$ Research Associate at the National Bureau of Standards, representing the Non-ferrous Ingot Metal Institute.

2 Figures in brackets indicate the literature references at the end of this paper.
} 
Metal Institute under the research associate plan. All arrangements for the concluding phase of the work were made by the senior author as research associate, and all the test data were obtained by him with the exception of those relating to the effects of an atmosphere of carbon monoxide. This portion of the work, together with the preparation of the report, has been the contribution of the junior authors.

\section{METHOD OF INVESTIGATION AND MATERIALS}

The general method followed in the investigation has already been described [1]. Only brief mention is required here. An ample stock supply of the alloy, $\mathrm{Cu} 85, \mathrm{Sn} 5, \mathrm{~Pb} 5, \mathrm{Zn} 5$, was initially prepared from virgin metals. Portions of this stock alloy were then remelted as needed, specific impurities in predetermmed amounts were added, and from the melt were cast the specimens necessary for the determination of the effects of these impurities on various characteristic properties of the alloy. This procedure was followed in the phase of the investigation covered by the present report. The incorporation of "gaseous" impurities into the molten metal was accomplished by remelting a charge of the stock alloy in an atmosphere consisting of the gas whose effect was to be determined. Atmospheres of hydrogen, methane, nitrogen, carbon dioxide, carbon monoxide, and air, respectively, were used. These gases were considered to be the principal constituents of the furnace atmosphere in which metals are melted in commercial practice.

A charge of approximately 85 pounds of the stock alloy was melted in a commercial clay-graphite crucible, the surface of which had been coated in a special manner. A satisfactory coating of a noncarbonaceous material was made by using a mixture of Aloxite cement in molasses diluted with water. A coating of the mixture applied with a brush was allowed to air-dry and then was heated with a flame. After this, it was heated to redness to burn from the molasses any carbonaceous material which might contaminate the special gas used as the enveloping atmosphere. Several applications were required in order to form a coating of sufficient thickness. The crucible was of a special double-walled type, which was needed to prevent excessive drop of temperature during the pouring of the required series of test specimens, as described in the previous reports.

The various gases used to furnish the desired atmospheres to surround the charge during melting were purchased from commercial sources in compressed form. The crucible and accompanying equipment as assembled for melting are shown diagrammatically in figure 1. Gas of the desired composition was conducted into the covered crucible at a rate of $40 \mathrm{ft}^{3}$ per hour to displace the air initially present, and the flow was continued during the melting and also as the metal was being poured into the specimen molds.

The gas played on the surface of the charge and was not bubbled through the molten metal. Advantage was taken of the characteristic stirring action of the high-frequency current on a molten metal to facilitate the action between the molten metal and the ambient atmosphere. Two heats were prepared for each type of atmosphere used, except in the case of nitrogen and air, for which three heats were prepared. The high-frequency induction furnace was of the "lift- 

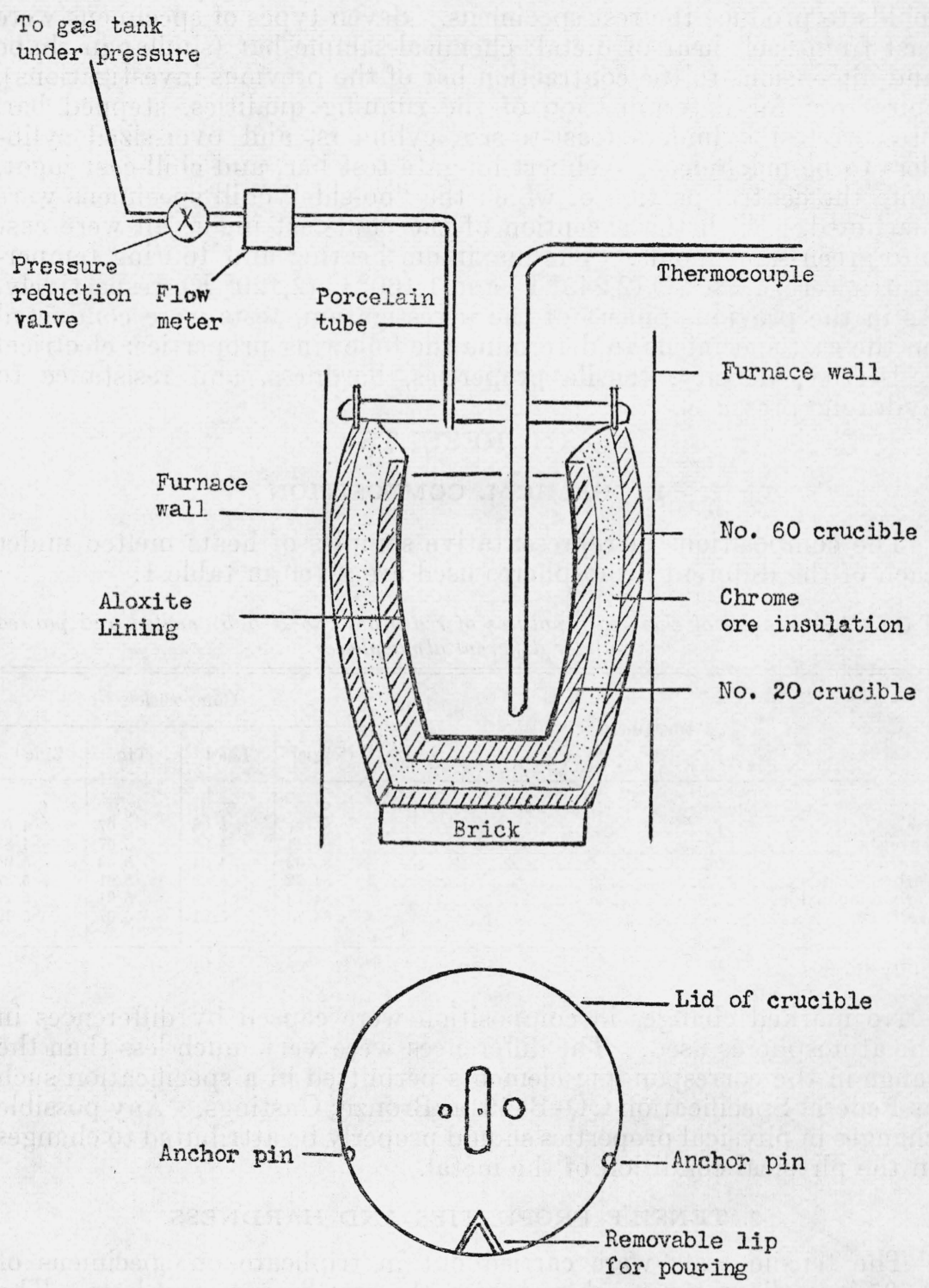

FIGURE 1.-Schematic representation of the control and maintenance of the atmosphere during melting. 


\section{Journal of Research of the National Bureau of Standards}

coil" type. At the close of the heating period the coil was raised above the crucible of molten metal, and the flow of gas into the crucible was interrupted only momentarily. The gas was allowed to flow into the crucible as the molten metal was being poured into the molds to produce the test specimens. Seven types of specimens were cast from each heat of metal: chemical-sample bar (similar in shape and dimensions to the contraction bar of the previous investigations), spiral rod for determination of the running qualities, stepped bar, pressure-test cylinders (cast-to-size cylinders, and over-sized cylinders to be machined), Webbert fin-gate test bar, and chill-cast ingot, from the central portion of which the "no-side" chill specimens were machined. With the exception of the chill-cast ingoc, all were cast into green-sand molds. The maximum heating and touring temperatures were, $1,230^{\circ} \mathrm{C}\left(2,245^{\circ} \mathrm{F}\right)$ and $1,160^{\circ} \mathrm{C}\left(2,120^{\circ} \mathrm{F}\right)$, respectively. As in the previous phases of the investigation, tests were conducted on the cast specimens to determine the following properties: electrical resistivity, density, tensile properties, hardness, and resistance to hydraulic pressure.

\section{RESUL'TS}

\section{CHEMICAL COMPOSITION}

The compositions of representative samples of heats melted under each of the different atmospheres used are given in table 1.

TABLE 1.-Results of chemical analyses of red brass (85-5-5-5) melted and poured under different atmospheres

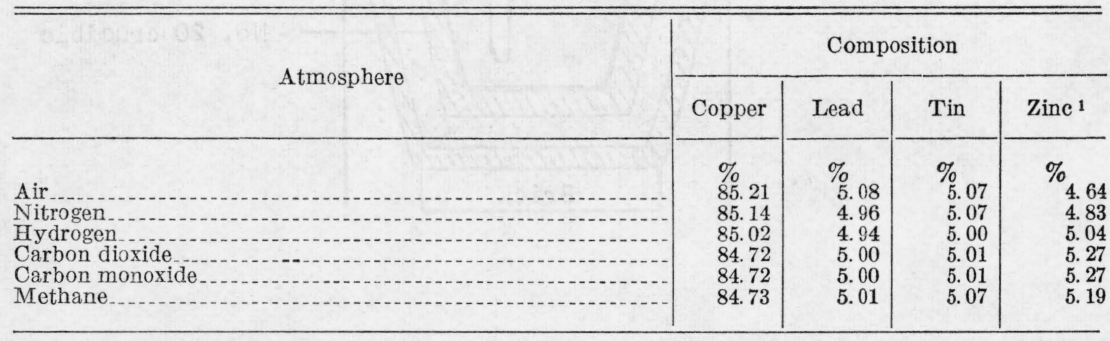

1 By difference.

No marked changes in composition were caused by differences in the atmospheres used. The differences were very much less than the range in the corresponding elements permitted in a specification such as Federal Specification QQ-B-691a, Bronze; Castings. Any possible changes in physical properties should properly be attributed to changes in the physical condition of the metal.

\section{TENSILE PROPERTIES AND HARDNESS}

The tensile tests were carried out in triplicate on specimens of 0.505-inch diameter, machined from the cast fin-gate test bars. The tests were conducted on a hydraulically operated machine of 50,000pound capacity. The yield-strength determinations were based on the "off-set" method (0.001 inch per inch). The average results of the tensile tests are summarized graphically in figures 2 and 3 . It will be noted that the tensile properties for the sand-cast bars (fig. 2) were consistently lower than the corresponding values for the no-side-chill 
bars (fig. 3) in all the atmospheres used. If the results obtained in air are used as the basis of comparison, and account is taken of the deviations in the various measurements, the data in table 2 indicate that the only atmospheres consistently producing significant reductions in tensile properties were hydrogen and methane.

Brinell indentations were made on the threaded ends of the broken

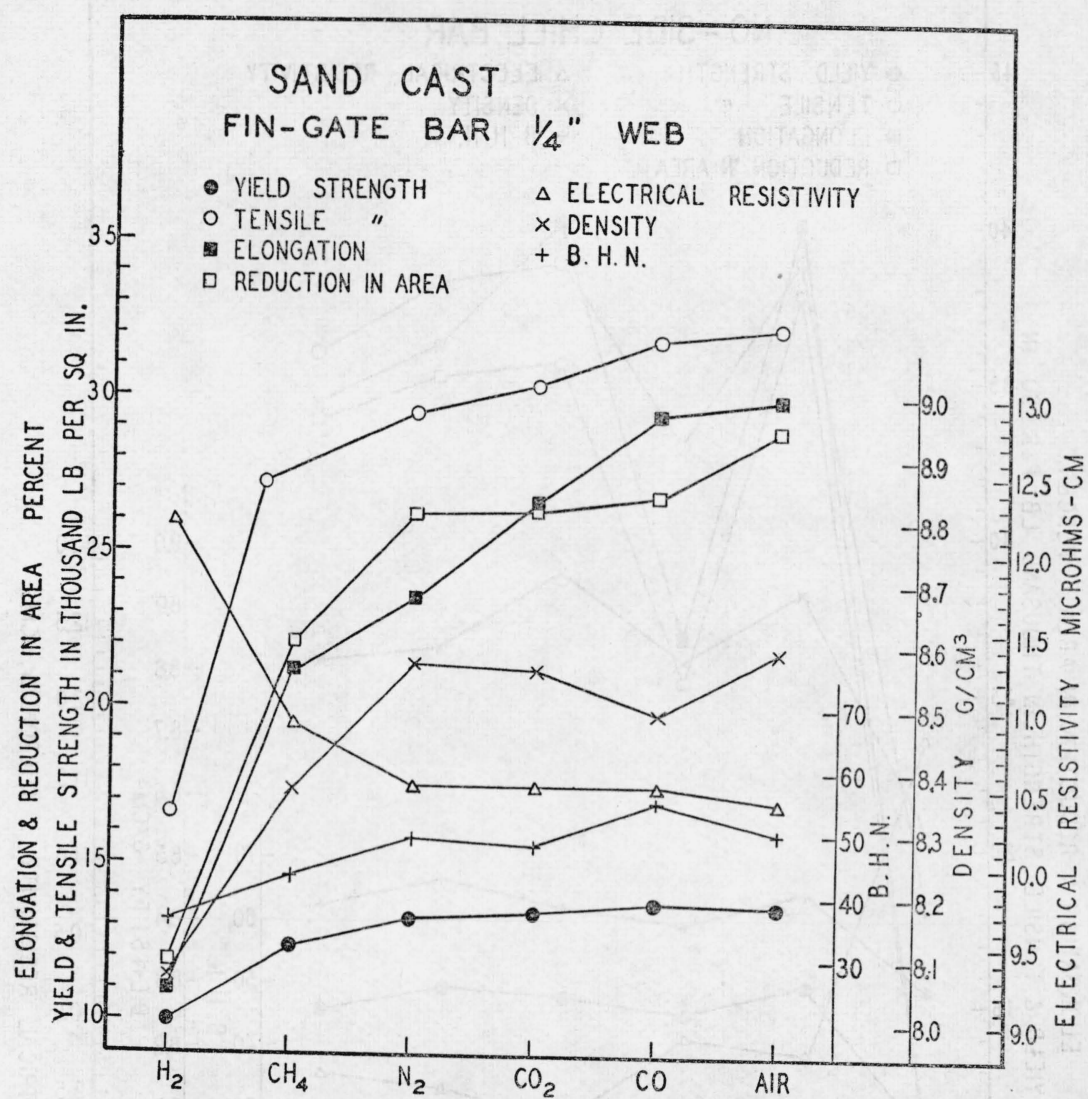

FIGURE 2.-Effect of different atmospheres during the melting of red brass (85 Cu, $5 \mathrm{Sn}, 5 \mathrm{~Pb}, 5 \mathrm{Zn})$ on its physical properties as determined on sand-cast fin-gate test bars.

(The lines connecting points do not represent properties between the points, i.e., no interpolation can be made. They have been drawn only as an aid in the interpretation of the data.)

tensile-test bars after they had been machined to produce longitudinal parallel flat faces, $5 / 8$ inch wide. The indentations were made with a $500-\mathrm{kg}$ load applied to a $10-\mathrm{mm}$ ball for 30 seconds. The results are given in figures 2 and 3 , and in table 3 . The effect of the enveloping atmospheres on the hardness of the cast metal was not nearly as pronounced as on the corresponding tensile properties, although the general trend was the same. The differences in the hardness of the sand-cast and of the chill-cast specimens were not so marked as of the tensile properties. 


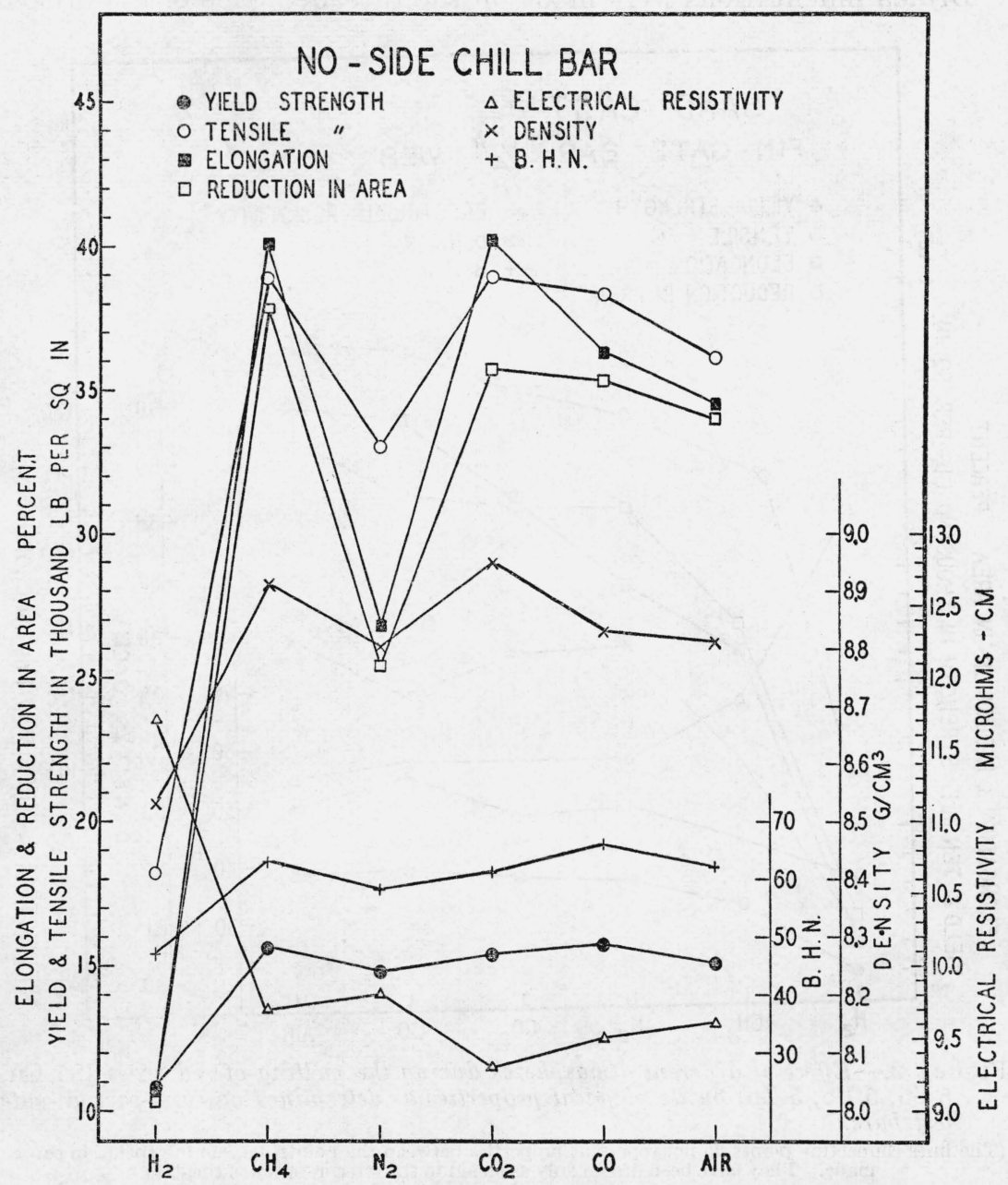

FIgURE 3.-Effect of different atmospheres during the melting of cast red brass $(85 \mathrm{Cu}, 5 \mathrm{Sn}, 5 \mathrm{~Pb}, 5 \mathrm{Zn})$ on its physical properties as determined on no-sidechill test bars.

(The lines connecting points do not represent properties between the points, i.e., no interpolation can be made. They have been drawn only as an aid in the interpretation of the data.) 
TABLE 2.-Tensile properties determined on Webbert and no-side chill test bars of $85 \mathrm{Cu}, 5 \mathrm{Sn}, 5 \mathrm{~Pb}, 5 \mathrm{Zn}$ red brass melted and poured under different atmospheres

\begin{tabular}{|c|c|c|c|c|c|c|c|c|c|c|c|c|c|}
\hline \multirow[b]{2}{*}{ Atmosphere } & \multicolumn{4}{|c|}{ Yield strength } & \multicolumn{3}{|c|}{ Tensile strength } & \multicolumn{3}{|c|}{ Elongation } & \multicolumn{3}{|c|}{$\begin{array}{l}\text { Reduction of } \\
\text { area }\end{array}$} \\
\hline & Test bar & 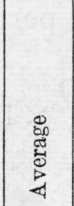 & 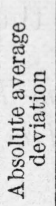 & 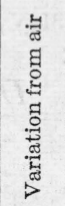 & 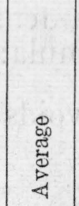 & 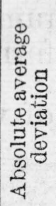 & 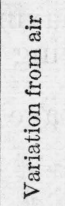 & 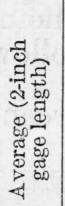 & 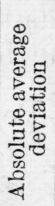 & 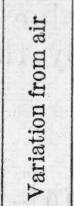 & 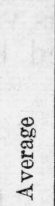 & 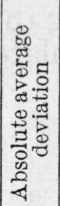 & 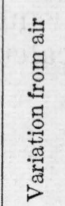 \\
\hline & Sand cast. & $\begin{array}{r}l b / \text { in } \\
13,700\end{array}$ & $\begin{array}{l}\% \\
1.1\end{array}$ & $\%$ & $\begin{array}{c}l b / i n t \\
32,200\end{array}$ & $\begin{array}{l}\% \\
2.8\end{array}$ & $\%$ & $\begin{array}{l}\% \\
29.9\end{array}$ & $\begin{array}{l}\% \\
8.3\end{array}$ & $\%$ & $\begin{array}{l}\% \\
28.9\end{array}$ & $\begin{array}{l}\% \\
0.8\end{array}$ & $\%$ \\
\hline $\mathrm{DO}_{-}$ & Chill cast. & 15,100 & $\begin{array}{l}1.1 \\
3.2\end{array}$ & & 36,100 & 9.0 & & 34.5 & 22.9 & & 34.0 & $\begin{array}{l}0.8 \\
7.8\end{array}$ & \\
\hline ydroger & Sand cast. & 10,000 & 2.4 & -27.0 & 16. 600 & 3.9 & -48.4 & 11. 0 & 3. 8 & -63.2 & 11. 9 & 6.1 & -59.0 \\
\hline Do & Chill cast. & 10,800 & 3.3 & -28.0 & 18,200 & 2.0 & -49.6 & 10.7 & 7.0 & -69.0 & 10.3 & 2. 2 & -70.0 \\
\hline Methane & Sand cast.. & 12,400 & $\begin{array}{l}1.0 \\
1.0\end{array}$ & -9.5 & 27,200 & 2.4 & -15.5 & 21. 2 & 6.1 & -29.1 & 22.1 & 18.5 & -23.5 \\
\hline Do & Chill cast.. & 15,600 & 0.5 & +3.3 & 38,900 & 1.3 & +7.8 & 40.1 & 2.7 & $\begin{array}{r}-16.2 \\
\end{array}$ & 37.9 & $\begin{array}{rl}5.8 & 0\end{array}$ & $\begin{array}{l}21.5 \\
+11.5\end{array}$ \\
\hline Nitrogen & Sand cast.- & $13,3 \cap 0$ & .9 & -3.0 & 29,400 & 3.4 & -8.7 & 23.5 & 9.2 & -21.4 & 26.2 & $\begin{array}{l}0.0 \\
8.8\end{array}$ & -9.3 \\
\hline Do. & Chill cast. & 14,800 & 10.5 & -2.0 & 33,000 & 23.6 & -8.6 & 26.8 & 43. 8 & -22.3 & 25.4 & \begin{tabular}{|r|}
39.3 \\
9.3
\end{tabular} & -25.3 \\
\hline Carbon dioxide & Sand cast.. & 13,500 & 1. 3 & -1.5 & 30,300 & 6.2 & -6 & 26.6 & 19. 8 & -11.0 & 26. 3 & \begin{tabular}{|l|}
14.3 \\
\end{tabular} & -9.0 \\
\hline Do & Chill cast & 15,400 & 0.3 & -3.1 & 38,900 & 1.4 & +8.0 & 40.2 & 5.6 & +16.5 & 35.7 & $\begin{array}{r}5.4 \\
5.4\end{array}$ & $+5,0$ \\
\hline Carbon monoxide & Sand cast.. & 13,800 & 1. 2 & +0 . & 31,800 & 4.1 & -1.2 & 29.4 & 16. 3 & -1.7 & 26.8 & $\begin{array}{l}0.1 \\
9.1\end{array}$ & -7.2 \\
\hline Do & Chill cast.. & 15,700 & 0.8 & +4.0 & 38,300 & 2.3 & +6.1 & 36.3 & 11. 7 & +5.2 & 35.3 & 14.4 & +4.0 \\
\hline
\end{tabular}

\section{DENSITY}

Determinations of density were made on the threaded ends of the broken tensile bars as specimens. The results are given in figures 2 and 3 and in table 3 . The generalizations expressed concerning the difference in tensile properties of the two types of test bars and the relative effects of the different atmospheres on the metal hold, in general, also for density.

TABLE 3.-Average values of density, electrical resistivity and Brinell hardness determined on fin-gate, sand-cast, and no-side-chill test bars of $85 \mathrm{Cu}, 5 \mathrm{Sn}, 5 \mathrm{~Pb}$, $5 \mathrm{Zn}$, alloy melted and poured under different atmospheres

\begin{tabular}{|c|c|c|c|c|c|c|c|c|c|c|}
\hline \multirow[b]{2}{*}{ Atmosphere } & \multirow[b]{2}{*}{ Test bar } & \multicolumn{3}{|c|}{ Density } & \multicolumn{3}{|c|}{ Electrical resistivity } & \multicolumn{3}{|c|}{ Brinell hardness } \\
\hline & & $\begin{array}{l}\text { Den- } \\
\text { sity }\end{array}$ & $\begin{array}{l}\text { Abso- } \\
\text { lute } \\
\text { aver- } \\
\text { age de- } \\
\text { viation }\end{array}$ & $\begin{array}{l}\text { Varia- } \\
\text { tion } \\
\text { from } \\
\text { air }\end{array}$ & $\begin{array}{l}\text { Elec- } \\
\text { trical } \\
\text { resis- } \\
\text { tivity }\end{array}$ & $\begin{array}{l}\text { Abso- } \\
\text { lute } \\
\text { aver- } \\
\text { age de- } \\
\text { viation }\end{array}$ & $\begin{array}{l}\text { Varia- } \\
\text { tion } \\
\text { from } \\
\text { air }\end{array}$ & $\begin{array}{l}\text { Num- } \\
\text { ber }\end{array}$ & $\begin{array}{l}\text { Abso- } \\
\text { lute } \\
\text { aver- } \\
\text { age de- } \\
\text { viation }\end{array}$ & $\begin{array}{c}\text { Varia- } \\
\text { tion } \\
\text { from } \\
\text { air }\end{array}$ \\
\hline Air & Sand cast. & $\begin{array}{r}\mathrm{g} / \mathrm{cm}^{2} \\
8.59\end{array}$ & $\begin{array}{l}\% \\
0.3\end{array}$ & $\%$ & $\begin{array}{c}\text { Microhm. } \\
\mathrm{cm} \\
10.4\end{array}$ & $\begin{array}{l}\% \\
0.3\end{array}$ & $\%$ & 50 & $\begin{array}{l}\% \\
2.5\end{array}$ & $\%$ \\
\hline $\mathrm{Do}$ & Chill cast. & 8.81 & 1.3 & & 9.6 & $\begin{array}{l}0.0 \\
3.4\end{array}$ & & 62 & 4.4 & \\
\hline $\begin{array}{l}\text { ydrogen } \\
\text { Do }\end{array}$ & Sand cast. & 8. 07 & 0.5 & $\begin{array}{l}-6.0 \\
-3.2\end{array}$ & 12. 2 & 0.7 & +17.5 & 36 & 1.4 & -28.0 \\
\hline Methane... & Sand cast. & $\begin{array}{l}8.03 \\
8.37\end{array}$ & .9 & $\begin{array}{l}-3.2 \\
-2.6\end{array}$ & 10.9 & $\begin{array}{l}1.3 \\
0.6\end{array}$ & $\begin{array}{l}+22 . \\
+5\end{array}$ & $\begin{array}{l}47 \\
43\end{array}$ & $\begin{array}{l}2.7 \\
2.3\end{array}$ & $\begin{array}{l}-24.2 \\
-14.0\end{array}$ \\
\hline Do & Chill cast. & 8.91 & .1 & $\begin{array}{l}-2.0 \\
+1.1\end{array}$ & 9. & $\begin{array}{r}0.0 \\
.0\end{array}$ & +1. & 63 & 0.8 & $\begin{array}{l}-1.00 \\
+1.6\end{array}$ \\
\hline Nitrogen.. & Sand cast. & 8.57 & .4 & -0. & 10. & .5 & +1 & 49 & 3.0 & -2.0 \\
\hline Do ... & Chill cast & 8.80 & 2.2 & - . & 9. & 4.9 & +2 & 58 & 12.2 & -6.5 \\
\hline Carbon dioxide & Sand cast. & 8.56 & 0.4 & -.4 & 10.5 & 0.5 & +1 & 48 & 1.2 & -4.0 \\
\hline Do & Chill cast. & 8. 95 & 1 & +1.6 & 9.3 & .6 & -3.1 & 61 & 1.2 & -1.6 \\
\hline Carbon mon- & Sand cast. & 8.49 & .6 & -1.1 & 10.5 & .4 & +1.0 & 55 & 3.0 & +10 . \\
\hline $\begin{array}{l}\text { xide. } \\
\text { Do... }\end{array}$ & Chill cast. & 8.83 & .2 & +0.2 & 9.5 & .5 & -1.0 & 66 & 2.0 & +6.5 \\
\hline
\end{tabular}

Density determinations were also made on the four sections of the stepped-bars as specimens. These "steps" ranged in thickness from $5 / 16$ to $1 / 8$ inch. The results in table 4 are also given in figure 4 . To 
illustrate in a more striking manner the effects of the various factors on the unsoundness of the metal, the percentage of "voids" has been calculated by the method used by Pearson and Baker [5]. The maximum density obtained for the metal in the investigation was 8.96 $\mathrm{g} / \mathrm{cm}^{3}$ (no-side-chill bar from metal melted in carbon dioxide). By using this value as the maximum density, the percentage of voids was calculated by the following formula:

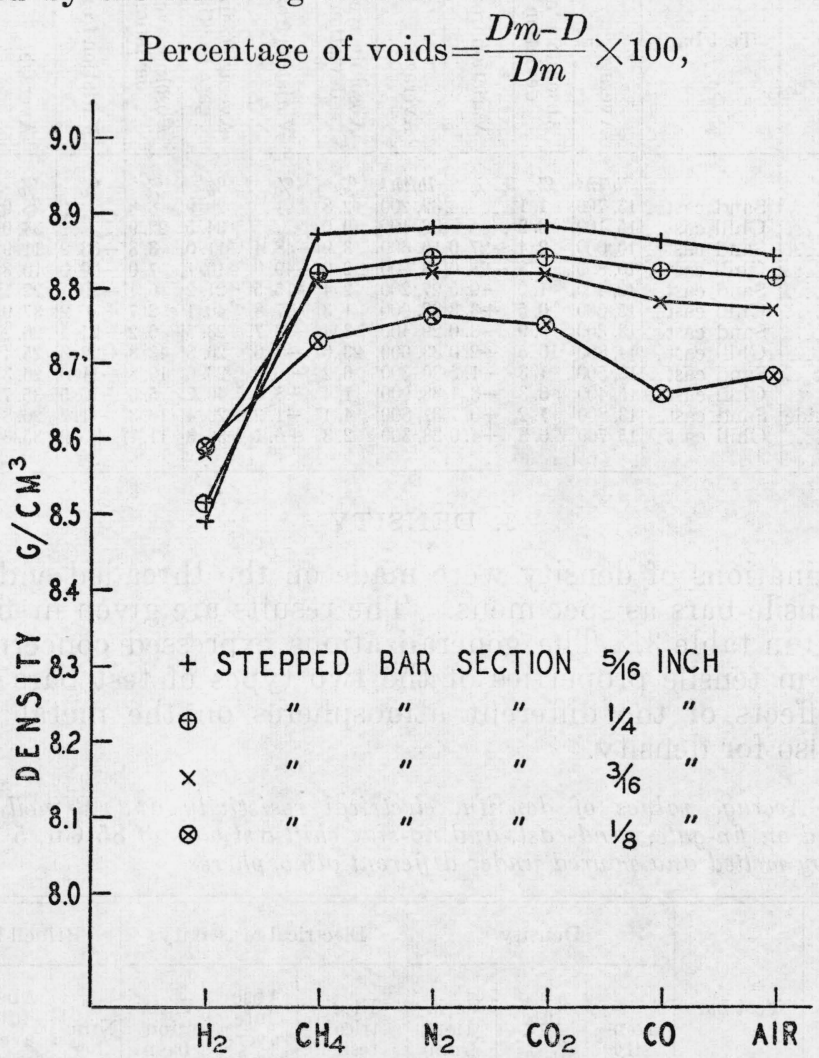

Figure 4.-Effect of different atmospheres during the melting of red brass $(85 \mathrm{Cu}$,

$5 \mathrm{Sn}, 5 \mathrm{~Pb}, 5 \mathrm{Zn}$ ) on its density as determined on stepped-bar castings.

in which $D m$ is the maximum density $\left(8.96 \mathrm{~g} / \mathrm{cm}^{3}\right)$ and $D$ is the observed density.

It is very apparent from the graphs (fig. 4) that the density of the specimens of metal melted under hydrogen was in all cases very significantly lower than that of metal melted under any of the other gases. Differences among the latter in all cases were of little significance. It is also apparent from figure 4 that, as the thickness of the "step" was decreased, the deleterious effect of hydrogen became somewhat less, that is, the unsoundness (voids) decreased somewhat. On the other hand, with all the other gases, as the thickness of the section was decreased, the unsoundness of the metal significantly increased, regardless of the atmosphere under which it had been melted and poured. 
TABLE 4.-Average values of density determined on sections of cast stepped bars of red brass which had been melted and poured under different atmospheres

\begin{tabular}{|c|c|c|c|c|c|c|c|c|c|c|c|c|}
\hline \multirow[b]{2}{*}{ Atmosphere } & \multicolumn{3}{|c|}{$5 / 16$ inch section } & \multicolumn{3}{|c|}{$1 / 4$ inch section } & \multicolumn{3}{|c|}{$3 / 16$ inch section } & \multicolumn{3}{|c|}{$1 / 8$ inch section } \\
\hline & 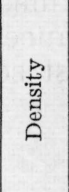 & 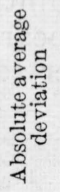 & 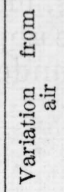 & 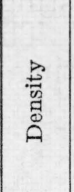 & 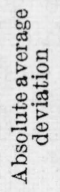 & 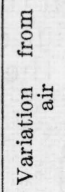 & 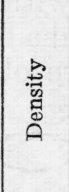 & 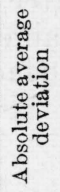 & 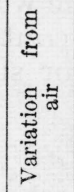 & 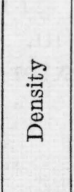 & 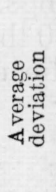 & 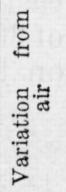 \\
\hline$A$ & $\begin{array}{l}\mathrm{g} / \mathrm{cm}^{3} \\
8.83\end{array}$ & $\%$ & $\%$ & $\begin{array}{c}\mathrm{g} / \mathrm{cm}^{3} \\
8.81\end{array}$ & $\%$ & $\%$ & $\begin{array}{l}\mathrm{g} / \mathrm{cm}^{3} \\
8.77\end{array}$ & $\begin{array}{l}\% \\
0.6\end{array}$ & $\%$ & $\begin{array}{c}\mathrm{g} / \mathrm{cm}^{3} \\
8.68\end{array}$ & $\%$ & $\%$ \\
\hline Hydrogen & 8.49 & .6 & -3.8 & 8.51 & .3 & -3.4 & 8. 58 & .1 & -2.2 & \begin{tabular}{|l|} 
\\
.59 \\
\end{tabular} & 1.0 & -1.1 \\
\hline Methane. & 8.87 & .2 & +0.5 & 8.82 & .4 & +0.1 & 8.81 & .4 & +0.5 & 8.73 & 0.5 & +0.6 \\
\hline Nitrogen. & 8.88 & .2 & +.6 & 8.84 & .2 & & 8.82 & .1 & & 8.76 & .2 & +.9 \\
\hline Carbon dioxide & 8.88 & .1 & +.6 & 8.84 & .2 & +.3 & 8.82 & .2 & +.6 & 8.75 & .3 & +.8 \\
\hline Carbon monoxide & 8.86 & .1 & +3.4 & 8.82 & 2 & +.1 & 8.78 & .3 & +.1 & 8. 66 & .7 & \\
\hline
\end{tabular}

\section{ELECTRICAL RESISTIVITY}

Determinations of this property were carried out on the machined test specimens used subsequently for the tensile tests. The results obtained, which are shown in figures 2 and 3 and in table 3 , are consistent with the condition of the metal with respect to unsoundness, as shown by density determinations. The sand-cast specimens, the densities of which were low in comparison with the densities of the no-side-chill bars, were consistently higher in electrical resistivity. In both sets of specimens, however, those representative of metal which had been melted and poured under hydrogen possessed higher resistivity. The differences in resistivity among the specimens representative of the other atmospheres were relatively insignificant.

\section{RUNNING QUALITY}

As used here, "running quality" connotes the ability of molten metal to fill a sand mold of a specified size and form. The horizontal spiral mold described by Saeger and Krynitsky [6] was used, the length in inches of the spiral cavity filled by the metal being recorded as the measure of its running quality. The results are summarized in table 5. In general, the values obtained for the metal melted under the different atmospheres did not differ significantly.

TABLE 5.-Average values of the running qualities of red brass melted and poured under different gas atmospheres

Pouring temperature $1,150^{\circ} \mathrm{C}\left(2,100^{\circ} \mathrm{F}\right)$. (One spiral casting for each melt; two melts for each atmosphere).

\begin{tabular}{|c|c|}
\hline Atmosphere 1 & $\begin{array}{c}\text { Length of } \\
\text { spiral }\end{array}$ \\
\hline Hydrogen & Inches \\
Methane & 13.3 \\
Nitrogen & 12.2 \\
Carbon dioxide & 14.6 \\
Air & 15.0 \\
& 13.6 \\
\hline
\end{tabular}

\footnotetext{
1 No tests were conducted with metal melted under carbon monoxide. A rather long interval elapsed between the tests with the 5 gases listed and those with carbon monoxide. During the interval, changes in the design of the spiral pattern were made, which rendered the results obtained by its use not strictly comparable with those obtained with the pattern previously used.
} 


\section{SOUNDNESS OF CASTINGS}

Hydraulic pressure testing of hollow cylindrical castings, cast as shown in figure 5 , was used to determine the soundness of finished castings. The water within the castings, maintained under a pressure of $300 \mathrm{lb} /$ in. $^{2}$, contained a blue dye. The appearance of blue coloration on the exterior surface of the casting under test served as evidence

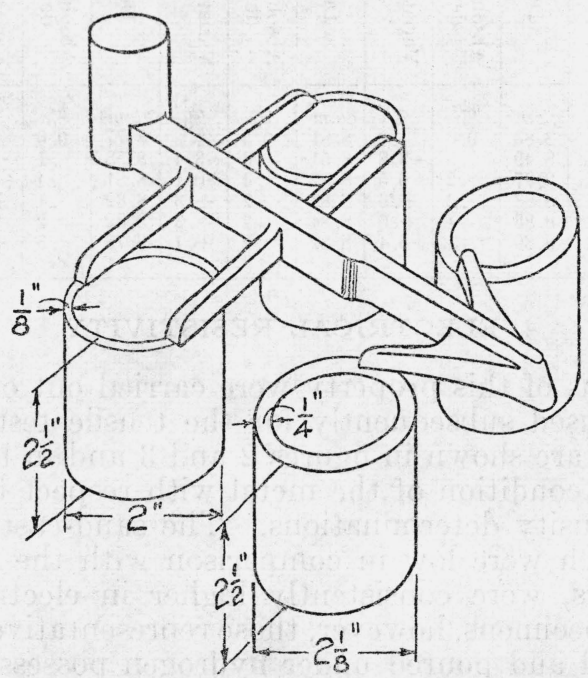

Figure 5.-Cast hollow cylinders used in pressure tests.

of leakage outward through the 1/4-inch wall of the cylinder. If no evidence of leakage was found after the pressure had been maintained for a 1-minute period, the specimen casting was rated $S$, sound, and those that failed, as NS, not sound. Specimens which satisfactorily withstood this test were subjected subsequently to a pressure of 600 lb/in. ${ }^{2} \quad$ The results are summarized in tables 6 and 7 . 
TABLE 6.-Results of hydraulic pressure tests of hollow cylinders of red brass

\begin{tabular}{|c|c|c|c|c|}
\hline \multicolumn{2}{|c|}{ Kind of specimen } & \multicolumn{2}{|c|}{$\begin{array}{c}\text { Behavior under } \\
\text { pressure }^{1}\end{array}$} & \multirow{2}{*}{ Remarks } \\
\hline $\begin{array}{l}\text { Cast-to- } \\
\text { size }\end{array}$ & $\begin{array}{c}\text { Machined } \\
\text { to-size }\end{array}$ & $200 \mathrm{lb}$. & $600 \mathrm{lb}$. & \\
\hline \multicolumn{5}{|c|}{ HYDROGEN } \\
\hline $\begin{array}{c}x \\
x \\
x \\
x\end{array}$ & $\frac{x^{x}}{x^{x}}$ & $\begin{array}{c}S \\
N S \\
N S \\
N S \\
S \\
S \\
N S \\
N S\end{array}$ & \begin{tabular}{c}
$S$ \\
- \\
\hdashline$S$ \\
$S$ \\
\hdashline-
\end{tabular} & $\begin{array}{l}\text { Porous at } 200 \mathrm{lb} . \\
\text { Very porous at } 100 \mathrm{lb} . \\
\text { Do. } \\
\text { Very porous at } 100 \mathrm{lb} \text {. } \\
\text { Do. }\end{array}$ \\
\hline \multicolumn{5}{|c|}{ METHANE } \\
\hline $\begin{array}{c}x \\
x \\
x \\
x\end{array}$ & $\frac{x^{x}}{x^{x}}$ & $\begin{array}{c}S \\
S \\
N S \\
N S \\
S \\
S \\
S \\
S\end{array}$ & $\begin{array}{c}S \\
S \\
- \\
S \\
S \\
S \\
S\end{array}$ & $\begin{array}{l}\text { Porous at } 250 \mathrm{lb} \text {. } \\
\text { Porous at } 200 \mathrm{lb} \text {. }\end{array}$ \\
\hline
\end{tabular}

\begin{tabular}{|c|c|c|c|c|}
\hline $\begin{array}{c}\begin{array}{c}x \\
x\end{array} \\
x \\
x \\
x \\
x \\
x\end{array}$ & $\begin{array}{l}x^{x} \\
x \\
x \\
x^{x} \\
x\end{array}$ & $\begin{array}{c}N S \\
S \\
N S \\
S \\
S \\
S \\
S \\
S \\
S \\
S \\
S \\
N S\end{array}$ & $\begin{array}{c}-S \\
S \\
S \\
S \\
S \\
S \\
S \\
S \\
S \\
-\end{array}$ & $\begin{array}{l}\text { Slightly porous at } 300 \mathrm{lb} . \\
\text { Porous at } 150 \mathrm{lb} .\end{array}$ \\
\hline
\end{tabular}

CARBON DIOXIDE

\begin{tabular}{|c|c|c|c|c|}
\hline $\begin{array}{c}\frac{x}{x} \\
x \\
x \\
x\end{array}$ & $\begin{array}{l}x \\
x \\
x \\
x\end{array}$ & $\begin{array}{c}S \\
S \\
N S \\
N S \\
S \\
S \\
N S \\
N S\end{array}$ & \begin{tabular}{c}
$S$ \\
$S$ \\
\\
$S$ \\
$S$ \\
\hdashline- \\
-
\end{tabular} & $\begin{array}{l}\text { Porous at } 300 \mathrm{lb} \text {. } \\
\text { Do. }\end{array}$ \\
\hline
\end{tabular}

CARBON MONOXIDE

\begin{tabular}{|c|c|c|c|c|}
\hline X & $\begin{array}{l}x \\
x \\
x\end{array}$ & $\begin{array}{c}S \\
N S \\
N S \\
N S \\
N S \\
N S \\
N S \\
N S\end{array}$ & $\begin{array}{c}S \\
\\
\cdots \\
\cdots \\
\cdots \\
\cdots \\
\cdots\end{array}$ & $\begin{array}{l}\text { Slightly porous at } 150 \mathrm{lb} \text {. } \\
\text { Very porous. Leak started } \\
\text { at } 50 \mathrm{lb} \text {. } \\
\text { Slightly porous at } 200 \mathrm{lb} \text {. } \\
\text { Slightly porous ta } 150 \mathrm{lb} \text {. } \\
\text { Do. } \\
\text { Slightly porous at } 50 \mathrm{lb} \text {. } \\
\text { Porous at } 100 \mathrm{lb} \text {. }\end{array}$ \\
\hline
\end{tabular}

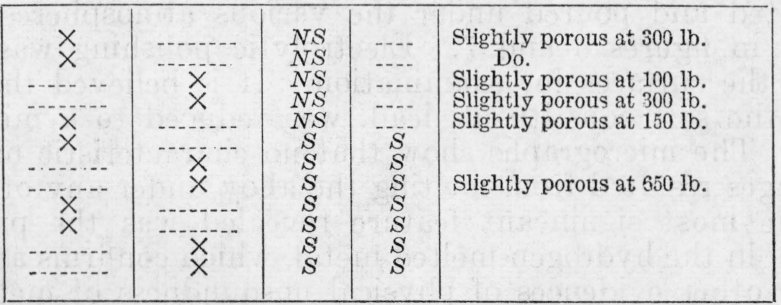

'S, sound (no leakage under pressure); NS, not sound (leakage under pressure). 
TABLE 7.-Summary of results of the hydraulic pressure tests

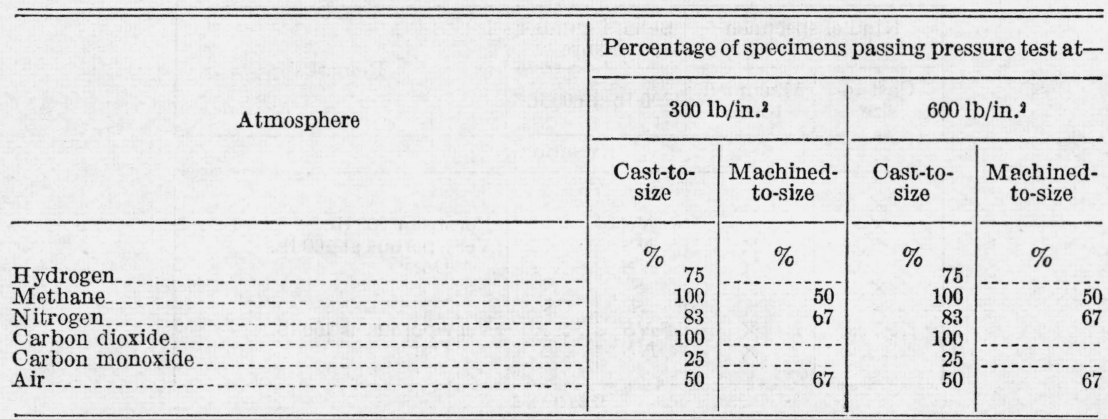

The results of previous investigations have shown the cast-to-size specimens to be more impervious to leakage of water under pressure than companion "over-sized" specimens which had been machined to size. The superiority of the cast-to-size casting has been attributed to the presence of a surface "skin." With one exception, similar results were obtained with the castings representative of the metal which had been melted and poured under a special atmosphere. The exception, metal melted and poured in air, is unexplainable, since the results of the similar tests with metal melted in air in the earlier phases of the investigation [4] were consistent with the general rule.

The results of the tests summarized in a foregoing section showed that metal melted under hydrogen is, as a rule, physically unsound. It will be noted, however (table 7), that the unmachined castings of such hydrogen-treated metal were definitely superior to companion castings of metal which had been melted under carbon monoxide, and only slightly inferior to castings of nitrogen-melted metal. For specimens in the machined condition, however, the situation was changed. All of the cylinders of hydrogen-melted metal leaked under pressure, as did also those representative of metal melted under carbon monoxide and carbon dioxide. The fact is noteworthy that all of the specimens, cast-to-size or machined-to-size, which withstood the pressure of $300 \mathrm{lb} / \mathrm{in}^{2}{ }^{2}$ without leaking, also withstood satisfactorily the higher pressure, $600 \mathrm{lb} / \mathrm{in} .^{2}$

It is evident that physical unsoundness, as based upon density and the results of mechanical tests, is not a satisfactory single criterion of the behavior of the castings under pressure, especially if the casting has not been machined prior to testing.

\section{MICROSTRUCTURE}

Micrographs representative of the structure of the metal after being melted and poured under the various atmospheres used are assembled in figures 6 and 7 . Electrolytic polishing was used for preparing the surfaces for examination. It is believed that the removal of the soft constituent, lead, was reduced to a minimum in this way. The micrographs show that no characteristic microstructural changes resulted from melting the alloy under any of the gases used. The most significant feature revealed was the presence of large voids in the hydrogen-melted metal, which confirms and supplements the other evidences of physical unsoundness of metal melted under hydrogen. 


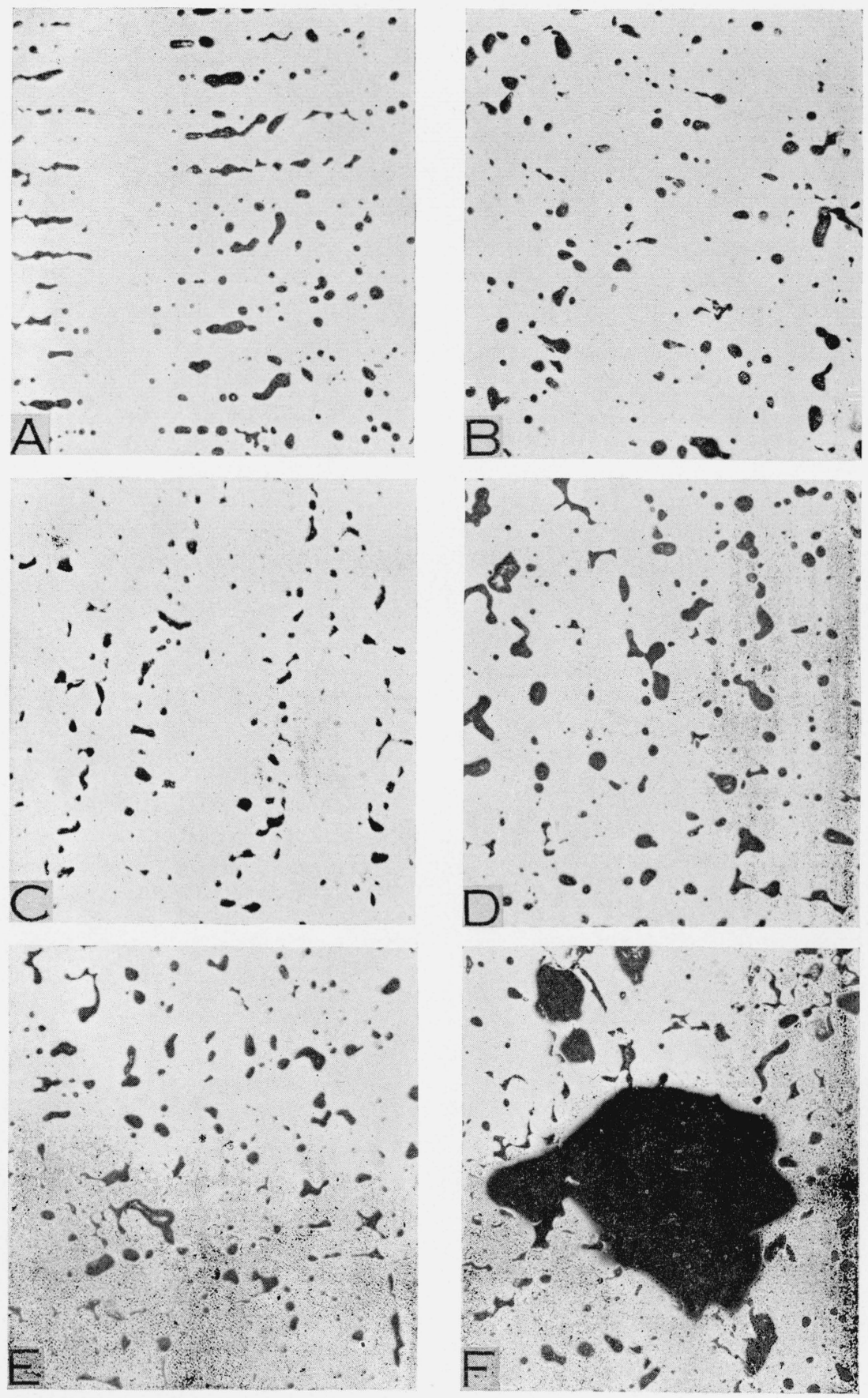

Figure 6.-Structure of red brass $(85 \mathrm{Cu}, 5 \mathrm{Sn}, 5 \mathrm{~Pb}, 5 \mathrm{Zn})$ melted and poured under the different atmospheres.

$A$, Air; $B$, nitrogen; $C$, carbon monoxide; $D$, carbon dioxide; $E$, methane; $F$, hydrogen. 

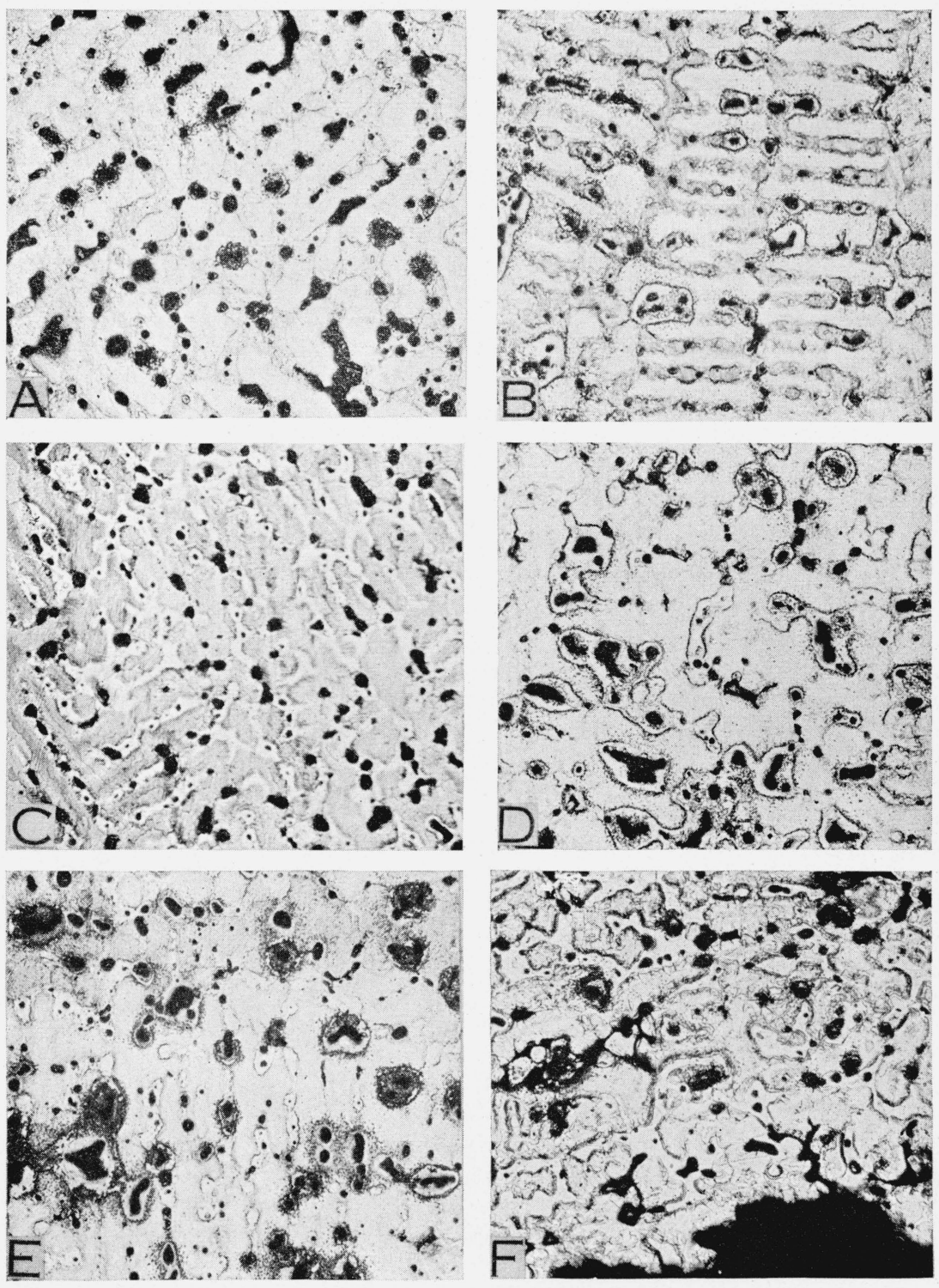

Figure 7.-Structure of red brass ( $85 \mathrm{Cu}, 5 \mathrm{Sn}, 5 \mathrm{~Pb}, 5 \mathrm{Zn})$ that has been melted and poured under different atmospheres. 
It has been demonstrated by Allen [7] that porosity of commercial copper ingots consists of a large number of very minute holes very evenly distributed. The unsoundness of the hydrogen-metal alloy, on the other hand, consisted invariably of relatively large cavities joined together at the center of the ingot. A reduction in the porosity, caused either by a decrease in the rate of cooling or by a reduction of the pressure of the gas under which the metal was melted, resulted in a decrease in the number of holes but not in their relative size.

\section{MELTING IN VACUUM}

Attempts were made, in a high-frequency induction furnace designed especially for such work, to melt the alloy and to cast it in vacuum. In the special furnace used, the metal after being melted in vacuo was poured into the mold without being removed from the evacuated melting chamber. A 30-pound charge of the alloy $(\mathrm{Cu}$, $84.4 ; \mathrm{Sn}, 5.00 ; \mathrm{Pb}, 4.95 ; \mathrm{Zn}, 5.65)$ was placed in a graphite crucible, and the furnace was evacuated to a pressure of $0.2 \mathrm{~mm}$ of mercury before the heating was started. Melting was started after 22 minutes of heating, but had to be discontinued 2 minutes later on account of the excessive volatilization of zinc which coated the observation window and threatened to damage the evacuating system or the heating coil.

\section{DISCUSSION}

The results summarized in the foregoing sections have definitely shown that no significant change in composition or microstructural condition results from melting red brass in any of the special atmospheres used. The decreases in strength and other properties which were noted must therefore be attributed to changes of some other kind. The changes in properties can be accounted for satisfactorily by the physical unsoundness of the specimens, which in some cases was very pronounced, particularly the specimens melted in an atmosphere of hydrogen. Since the unsoundness of the cast specimens arises during solidification, it follows that gas must have been held in solution in the molten metal and then evolved as freezing of the metal occurred. Two factors are therefore of interest: (a) the solubility of the different gases in the molten copper alloy, and (b) the effect of the rate of cooling during solidification on the evolution of the gas during freezing (or on its possible retention in the solidified metal).

Information in the technical literature on the effects on molten copper alloys of the gases used in this investigation is scanty and contradictory. Both Allen [7] and Daniels [9] have reported nitrogen, carbon monoxide, and carbon dioxide to be inert so far as producing physical unsoundness in copper and copper-base alloys is concerned. According to Daniels, these gases, if soluble at all in molten copper, are not liberated as bubbles as the metal solidifies under ordinary conditions. According to Pearson and Baker [5], carbon monoxide is only slightly soluble in molten bronze, $90 \mathrm{Cu}-10 \mathrm{Sn}$, and the mechanical properties are not seriously impaired thereby.

Hesse [8] assumed that vacuum melts of a $\mathrm{Cu}-\mathrm{Sn}-\mathrm{Ni}-\mathrm{Zn}$ alloy contained no gas and concluded that carbon monoxide did not promote porosity of the alloy. According to his results, hydrogen and water vapor were most effective in causing porosity, sulfur dioxide and air 
were next in order with a decided decrease in porosity, and carbon dioxide, nitrogen, oxygen, and carbon monoxide caused very slight porosity, the effect of carbon monoxide being least of all. In general, the conclusions expressed by the previous investigators were confirmed by the results of the present study. The tensile properties and the electrical resistivity of the cast alloy after melting and pouring in nitrogen, carbon dioxide, air, or carbon monoxide did not differ significantly for the different atmospheres.

All investigators agree, however, that the effect of hydrogen on the molten metal is distinctly different. According to Bailey [10], hydrogen is readily soluble in many molten metals and Pry therch [11] showed that hydrogen is soluble in molten copper and that its solubility is markedly reduced at the freezing point of copper. Decided difference of opinion has been expressed concerning the practical significance of the decreased solubility at the freezing temperature. According to Prytherch, this change results in unsoundness when copper is chillcast, although the degree of unsoundness may vary with the rate of solidification and other conditions. Allen [7] has stated that, whereas commercial copper chill-cast is dense, the reverse is true for hydrogentreated copper. A chill-cast ingot of such copper is unsound, and the numerous large holes formed show a tendency to join together at the center of the ingot. On slower cooling, however, fewer holes are formed, and if the cooling rate is slow enough none are formed. Substantially the same conclusion was expressed by Daniels [9] concerning the cooling rate of hydrogen treated bronze $(88 \mathrm{Cu}, 10 \mathrm{Sn}$, $2 \mathrm{Zn})$.

Bailey [10], on the other hand, has reported differently, basing his conclusions on investigations made by the British Nonferrous Metals Research Association. The effect on the soundness of bronze (5 percent of tin) produced by bubbling hydrogen through the molten metal for 30 minutes, together with the results of a similar test with nitrogen for 60 minutes, are summarized below.

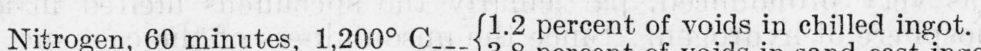

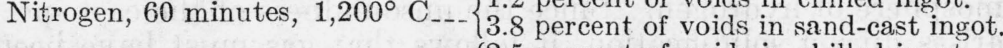

Hydrogen, 30 minutes, $1,190^{\circ} \mathrm{C}_{-}-\left\{\begin{array}{l}2.5 \text { percent of voids in chilled ingot. } \\ 9.7 \text { percent of voids in sand-cast ingot. }\end{array}\right.$

If it is assumed that the unsoundness after nitrogen treatment is due to shrinkage only, the increased unsoundness after hydrogen treatment must be associated with the evolution of hydrogen during solidification. If this assumption is granted, it will be noted that hydrogen treatment increased the voids in the chill-cast bars by 1.3 percent and in the sand-cast bars by 5.9 percent. As stated by Bailey, it is difficult to explain this except by the retention of more gas in solid solution in the case of the chill-cast bars. Definite evidence is lacking as to whether rapid cooling causes the retention of gas (hydrogen) in the metal in the solid state.

At the temperature of casting (about $1,200^{\circ} \mathrm{C}$, or $2,200^{\circ} \mathrm{F}$ ) methane is appreciably dissociated into hydrogen and carbon. It is probable that the hydrogen thus liberated behaves like the hydrogen introduced directly in the other tests.

Although no data are available on the rate of solidification of the specimens cast in the present investigation, there can be no doubt that the cooling rate of the chill-mold castings was greater than that of the sand-cast (Webbert) bars. It may also be safely assumed 
that the cooling rate of the chill-mold castings was only slightly greater than that of the stepped-bar casting. In the latter, the cooling rate of the various "steps" increased with decrease in thickness of the section. The greater soundness of the chilled castings relative to that of the sand-cast bars, as revealed by the superior strength and density and low electrical resistivity of the chill-cast metal, has already been presented. These results are not in line with those reported by Prytherch, Allen, and Daniels, but rather confirm Bailey's conclusion that more hydrogen is retained in solid solution in chill-cast metal than in sand-cast metal. Other supporting evidence is the fact that the soundness of the different "steps" of the stepped bars, melted and poured in a hydrogen atmosphere, increased with decrease in thickness of the section (fig. 4). The opposite results noted in the cases of the stepped bars, melted and cast in the other atmospheres, can be taken as indicative of greater evolution of these gases with increased rate of solidification.

\section{SUMMARY}

1. As the concluding phase of an extended investigation of red brass ( $\mathrm{Cu}, 85 ; \mathrm{Sn}, 5 ; \mathrm{Pb}, 5 ; \mathrm{Zn}, 5)$, the effects of gaseous "impurities" were studied. Such impurities might be expected according to the nature of the ambient atmosphere during melting and pouring of the metal. The general method used was the same as that used in previous phases, except that the melting and pouring of the stock alloy, which had been prepared from virgin metals, were carried out in a carefully controlled atmosphere. The following atmospheres were used: hydrogen, nitrogen, methane, carbon dioxide, carbon monoxide, and air.

2. Chemical analysis of the metal, after being melted and poured under the various gases used as enveloping atmospheres, showed no significant changes in composition.

3 . The effect of the ambient atmosphere on the tensile properties, hardness, and density of red brass melted therein was found to be different for sand-cast specimens than for chill-cast specimens. The properties of the sand-cast bars in general were inferior to those of the other set. For both the sand-cast and chill-cast bars, hydrogen and methane had deleterious effects. In both cases, the detrimental effect of hydrogen was most pronounced.

4. Regardless of the atmosphere under which the alloy was melted, the electrical resistivity of the chill-cast bars was considerably lower than that of the comparison bars cast in sand. In both cases, however, the electrical resistivity of the hydrogen-treated metal was much higher than that of the alloy melted under other gases.

5 . The soundness of finished castings was determined by hydraulic pressure tests conducted on hollow cylinders by means of specimens cast-to-size and also over-size castings machined-to-size. The results of previous investigations were confirmed in showing the importance of the "skin" of the casting in securing superior resistance to leakage under pressure. This was true regardless of the special atmosphere under which the metal was melted. The highest percentage of specimens showing no leakage under pressure were representative of metal melted under an atmosphere of methane or nitrogen, the lowest percentage was for specimens of metal melted under carbon dioxide.

6 . The effect of section thickness on density was determined on $543158-43-2$ 
stepped-bar castings, the thickness of the various steps ranging from $5 / 16$ to $1 / 8$ inch. The density of hydrogen-melted metal was lower than that of the metal melted under any other atmosphere. It is noteworthy, however, that the soundness of the hydrogen treatment in the various "steps" increased with decrease in thickness of the section. The opposite condition obtained in all other cases.

7. The running quality of the metal, as shown by the length of a horizontal spiral sand-casting, was found not to differ significantly for the different atmospheres under which the metal had been melted.

8. Microscopic examination showed no significant change in the microstructure, which is typical of an alloy of the composition used. A high degree of unsoundness (voids) was found to be characteristic of the metal which had been melted under hydrogen. Practically all of the differences in properties noted for the specimens from the special atmospheres, can be satisfactorily explained on the basis of this structural feature.

9. Attempts to melt and cast the alloy in vacuum, without exposure to any atmosphere whatsoever, to secure other data on melting and casting resulted in complete failure on account of the excessive volatilization of zinc in the alloy.

10. The most important conclusion of this investigation is the marked deleterious effect of the hydrogen retained by the metal after being melted in a hydrogen atmosphere. The deleterious effect can be attributed to the unsoundness (voids) resulting as the gas is evolved from the solution.

Acknowledgment is made to L. D. Jones, senior molder, for his able assistance and helpful suggestions during the planning and progress of the work.

\section{REFERENCES}

[1] H. B. Gardner and C. M. Saeger, Jr., Factors affecting the physical properties of cast red brass $(85 \mathrm{Cu}, 5 \mathrm{Zn}, 5 \mathrm{Sn}, 5 \mathrm{~Pb}$ ), Proc. Am. Soc. Testing Materials 32, pt. II, 517 (1932).

[2] H. B. Gardner and C. M. Saeger, Jr., The effect of sulfur and iron on the physical properties of cast red brass ( $85 \mathrm{Cu}, 5 \mathrm{Sn}, 5 \mathrm{Zn}, 5 \mathrm{~Pb}$ ), Proc. Am. Soc. Testing Materials 33, pt. II, 448 (1933).

[3] C. M. Saeger, Jr., Studies of cast red brass for the establishment of a basic classification of non-ferrous ingot metals for specification purposes (Am. Foundrymen's Assn. exchange paper) Proc. Inst. Brit. Foundrymen 2\%, 268 (1933-34).

[4] H. B. Gardner and C. M. Saeger, Jr., The effects of aluminum and antimony on certain properiies of cast red brass, Trans. Am. Foundrymen's Assn. 4\%, 423 (1939).

[5] T. F. Pearson and W. A. Baker, Causes of porosity in tin-bronze castings, J. Inst. Metals 6\%, 231 (1941).

[6] C. M. Saeger, Jr. and A. I. Krynitsky, A practical method for studying the running qualities of a metal cast in foundry molds, Trans. Am. Foundrymen's Assn. 39, 513 (1931).

[7] N. P. Allen, Experiments on the influence of gases on the soundness of copper ingots, J. Inst. Metals 43, No. 1, 81 (1930).

[8] Alfred H. Hesse, Some causes for porosity and leakage in non-ferrous castings, Trans. Am. Foundrymen's Assn. 49, 331 (1941).

[9] Edward T. Daniels, Unsoundness in bronze castings, J. Inst. Metals 43, No. 1,125 (1930).

[10] G. L. Bailey, Effect of melting conditions on gas unsoundness in metals Foundry Trade J. 60, 576 (1939); 61, 9 (1939).

[11] W. E. Prytherch, Gases in copper and their removal, J. Inst. Metals 43, No. 1, $73(1930)$.

Washington, May 24, 1943. 